\title{
Analisis Status Hidrasi dan Asupan Zat Gizi Serta Air pada Ibu Hamil
}

\section{An Analysis of Hydration Status and Nutrient Water Intake in Pregnant Women}

\author{
Erry Yudhya Mulyani ${ }^{1,2 *}$, Hardinsyah ${ }^{1}$, Dodik Briawan ${ }^{1}$, \\ Budi Iman Santoso ${ }^{3}$
}

${ }^{1}$ Department of Community Nutrition, Faculty of Human Ecology, Bogor Agricultural University ${ }^{2}$ Department of Nutrition, Faculty of Health Sciences, Esa Unggul University, Jakarta, Indonesia ${ }^{3}$ Department of Obstetrics and Gynecology, Faculty of Medicine, Universitas Indonesia-Dr.Cipto Mangunkusumo General Hospital, Jakarta, Indonesia

(*erry.yudhya@esaunggul.ac.id)

\begin{abstract}
ABSTRAK
Kehamilan merupakan periode fisiologis-spesifik yang mana selama periode ini, kebutuhan zat gizi meningkat. Sebanyak 50-70\% ibu hamil mengalami mual dan muntah terus menerus, berdampak pada kurang maksimalnya pemberian asupan gizi bagi ibu dan bayi. Keberlanjutan kondisi ibu dapat menyebabkan ketidakseimbangan cairan di dalam tubuh yang berdampak pada status hidrasi ibu. Penelitian bertujuan menganalisis hubungan karakteristik, sosial-ekonomi, status gizi, asupan gizi dan air dengan status hidrasi. Penelitian ini merupakan penelitian cross-sectional, dilakukan di wilayah kerja Puskesmas Kecamatan Kebon Jeruk, Jakarta Barat. Subjek penelitian ini adalah ibu hamil trimester kedua, memeriksakan kehamilan di tempat penelitian berjumlah 107 subjek. Uji t-test independent dan chi-square digunakan untuk menganalisis data. Subjek dibagi ke dalam dua kelompok berdasarkan status hidrasi dari nilai osmolalitas urin; normal dan hipohidrasi. Nilai rerata osmolalitas urin pada kelompok hipohidrasi dan normal, adalah $838.78 \pm 172.35$ $\mathrm{mOsm} / \mathrm{Kg}$ dan $268.05 \pm 116.64 \mathrm{mOsm} / \mathrm{Kg}$. Karakteristik subjek (umur, umur kehamilan, berat badan, tinggi badan, status gizi sebelum hamil, lingkar lengan atas, lingkar pinggang, lingkar panggul, tekanan darah) tidak terdapat perbedaan di antara dua kelompok ( $\mathrm{p} \geq 0.05$ ). Tidak terdapat hubungan tingkat pendidikan ayah dan ibu, pekerjaan ayah dan ibu, pengeluaran rumah tangga, dan pengetahuan ibu ( $\mathrm{p} \geq 0.05)$. Terdapat perbedaan asupan energi, karbohidrat, dan zinc di dua kelompok ( $<<0.05)$, tetapi tidak menemukan perbedaan asupan (protein, lemak, kalsium, zat besi, asam folat) dan air di dua kelompok ( $\mathrm{p} \geq 0.05$ ). Namun demikian, ibu harus tetap memerhatikan asupan zat gizi dan air untuk mendukung tumbuh kembang janin.
\end{abstract}

Kata kunci : Asupan zat gizi dan air, status hidrasi, ibu hamil

\section{ABSTRACT}

Pregnancy is a specific physiological period, which is the nutritional requirements increase more than those of normal condition. About 50-70\% of pregnant women experience nausea and vomiting, it was affects to the lack of nutrient intake for mothers and infants. The sustainability of mother's condition can cause an imbalance of body fluid which has impact on the mother's hydration status. The aims of this study were to analyze the relationship between characteristics, socio-economic, nutritional status, nutritional intake and water with hydration status. This study was a cross sectional study, conducted on the area of primary of public health at Kebon Jeruk Regency, West Jakarta. The subject were pregnant women who in the second trimester, examined pregnancy in the study area amounted to 107 subjects. Independent t-test and chi-square test were used to analyzed the data. Subjects were divided into two groups based on hydration status from urin osmolality concentration; normal and hypohydrated. The average of urine osmolality in the hypohydration group and normal, were $838.78 \pm 172.35 \mathrm{mOsm} / \mathrm{Kg}$ and $268.05 \pm 116.64 \mathrm{mOsm} / \mathrm{Kg}$, respectively. Subject's characteristics (age, gestational age, body weight, height, nutritional status before pregnancy, upper arm circumference, waist circumference, hip circumference, blood pressure) did not differ between two groups ( $p \geq 0.05)$. There were no relationship between edu-cation of mothers and fathers, employment status of mothers and fathers, household expenditure, and mother's know-ledge ( $p \geq 0.05)$. There were differences of energy, carbohydrate and zinc intake between two groups $(p<0.05)$, but didn't found differences intake of (protein, fat, calcium, iron, folic acid) and water between two groups $(p \geq 0.05)$. However, the mother should more attention to fulfil their nutrients and water intakes to support the foetus growth.

\section{Keywords : Nutrients and water intake, hydration status, pregnant women}

Copyright (C) 2018 Universitas Hasanuddin. This is an open access article under the CC BY-NC-SA license (https://creativecommons.org/licenses/by-nc-sa/4.0/).

DOI : http://dx.doi.org/10.30597/mkmi.v14i3.4343 


\section{PENDAHULUAN}

Kehamilan merupakan periode fisiologis spesifik yang mana selama periode ini, kebutuhan zat gizi meningkat. Ketika kebutuhan zat gizi secara umum dapat dipenuhi melalui diet yang cukup, risiko kekurangan asupan zat gizi mikro pada kehamilan merupakan hal yang dapat diatasi seperti dengan makanan tambahan (suplemen ibu hamil). ${ }^{1}$ Di awal kehamilan yaitu usia 6-8 minggu, sebagian besar ibu hamil 50-70\% mengalami mual dan muntah. ${ }^{2}$ Apabila keadaan ini berlanjut dapat mengakibatkan Hyperemesis Gravidarum (HG), yang mana tubuh kehilangan banyak cairan, penurunan berat badan lebih dari 5\%, ketonuria, kelainan elektrolit (hipokalemia), dehidrasi, dan berat jenis urin (tinggi). ${ }^{3,4}$ Pada ibu hamil yang pernah dirawat dengan $\mathrm{HG}$ berisiko 29 kali lebih tinggi dirawat kembali di rumah sakit dari ibu yang tidak pernah dirawat.,

Kondisi hiperemesis gravidarum dapat memicu keterbatasan dalam mencapai kondisi pertumbuhan yang optimal dikarenakan tidak maksimalnya pemberian asupan gizi bagi ibu dan bayi, dan hiperemesis gravidarum meningkatkan stres serta dapat memicu respon fight-or-flight. Penelitian Lacasse et.al., tahun 2008 menyebutkan bahwa mual dan muntah memiliki dampak yang signifikan terhadap kehidupan keluarga serta kemampuan untuk melakukan kegiatan sehari-hari yang biasa, fungsi sosial, tingkat stres, dan keinginan untuk memiliki anak berikutnya. ${ }^{8}$

Kehilangan cairan melalui mual dan muntah yang berlebihan secara terus menerus menyebabkan ibu hamil mengalami dehidrasi. Dehidrasi merupakan proses dari kondisi yang terjadi pada seseorang ditandai dengan cairan yang keluar lebih besar daripada cairan yang masuk ke dalam tubuh. ${ }^{9}$ Di negara tropis seperti Indonesia ditemukan pada ibu hamil sebanyak $57.1 \%$ mengalami dehidrasi dengan memiliki riwayat mual dan muntah sebanyak $70.0 \% .^{10}$

Penelitian Louik et.al., tahun 2006 menemukan bahwa pada wanita yang memiliki pendidikan rendah, ekonomi menengah ke bawah, usia lebih tua, berkulit hitam, graviditas tinggi, kehamilan ganda, memiliki risiko lebih besar mengalami mual dan muntah. ${ }^{11}$ Selain faktor sosial-ekonomi yang secara tidak langsung mempengaruhi kondisi hidrasi ibu, faktor lain adalah berat badan dan asupan zat gizi dan air pada ibu. Penelitian Chortatos et al., tahun 2013 di Norwegia, menemukan bahwa ibu hamil dengan mual dan muntah memiliki kebiasaan asupan tinggi karbohidrat dan gula, terutama dari minuman ringan yang mengandung gula. ${ }^{12}$ Kondisi yang dialami ibu dapat mempengaruhi keseimbangan cairan tubuh (seperti natrium dan kalium) yang berdampak pada status hidrasi ibu. Penelitian sebelumnya di Yunani, menemukan bahwa ada perbedaan konsumsi air pada ibu yang dehidrasi dan tidak di tiap trimester kehamilan. ${ }^{13}$ Belum banyak penelitian yang melihat status hidrasi ibu dimasa kehamilan. Oleh karenanya, tujuan dari penelitian ini untuk memberikan gambaran hubungan karakteristik, sosial-ekonomi, status gizi, asupan gizi dan air dengan status hidrasi.

\section{BAHAN DAN METODE}

Penelitian ini merupakan penelitian cross sectional yang bertujuan memberikan gambaran karakteristik subjek, sosial-ekonomi, status gizi dan asupan gizi serta air berdasarkan status hidrasi ibu hamil. Penelitian dilakukan pada 1 Desember 2016 sampai dengan 30 Agustus 2017, bertempat di wilayah kerja Puskesmas Kecamatan Kebon Jeruk, Jakarta Barat terdiri dari 7 wilayah yaitu Puskesmas Kebon Jeruk, Puskesmas Sukabumi Selatan, Puskesmas Sukabumi Utara, Puskesmas Kedoya Utara, Puskesmas Kedoya Selatan, Puskesmas Duri Kepa, dan Puskesmas Kelapa Dua. Subjek penelitian adalah ibu hamil trimester kedua yang masuk dalam kriteria inklusi sebagai berikut; 1). Ibu hamil yang memeriksakan kandungan di puskesmas, 2). Telah memasuki trimester kedua (>12 minggu-24 minggu), 3). Sehat (tidak menderita infeksi sekunder) berdasarkan hasil pemeriksaan dokter, 4). Tidak pernah melahirkan BBLR dan bayi pendek $(<48 \mathrm{~cm}), 5)$. Usia ibu $>18-35$ tahun, 6). TB ibu 150-165 cm, 7). IMT 18.5-25.0, 8). Pernah mengalami infeksi saluran kemih berdasarkan rekam medis atau diagnosa dokter, 9). Pernah mengalami diare, mual dan muntah dari awal kehamilan sampai dengan penelitian, 10). Berencana melahirkan ditempat penelitian (puskesmas tertuju). 11). Mendapatkan penjelasan penelitian dan menyetujui informed consent,12). Bersedia untuk mematuhi prosedur penelitian, 13). Tidak pernah memiliki riwayat melahirkan sesar. Dalam penelitian ini didapat sebanyak 107 subjek ibu hamil 
yang bersedia mengikuti penelitian.

Data yang terkumpul dalam penelitian ini yaitu data karakteristik, data antropometri (berat badan, tinggi badan, lingkar lengan atas, lingkar pinggang-panggul) dan tekanan darah. Pengukuran antropometri ini dilakukan oleh enumerator terlatih dan bidan. Alat bantu pengukuran berat badan dengan timbangan berat badan digital $(0.1 \mathrm{~kg})$, mikrotoa untuk tinggi badan $(0.1 \mathrm{~cm})$, dan tensimeter manual (Riester)/air raksa dengan ketelitian $( \pm 3 \mathrm{mmHg})$. Perolehan data asupan zat gizi dan air dilakukan pada waktu yang sama saat pengambilan urin (16-18 minggu kehamilan) yaitu dengan metode wawancara recall 1x24 jam selama 3 hari ( 1 hari diwaktu pengukuran antropometri, 2 hari lainnya di hari berikutnya, dengan 1 hari libur) oleh enumerator terlatih. Sementara itu, pengukuran status hidrasi menggunakan indikator osmolalitas urin diambil oleh tenaga phelebotomi terlatih dan diperiksa pada laboratorium terakreditasi. Pengambilan urin pada pukul 14.01-16.00 WIB. Osmolalitas urin diperiksa dengan metode freezing point depression menggunakan alat Osmomat 3000 Gonotec GmBH.

Data diolah dan dianalisis dengan program Microsoft Office Excel dan SPSS. Data yang telah dikumpulkan tersebut dianalisis secara deskriptif dan disajikan dalam bentuk nilai rerata (mean), median, Standar Deviasi (SD). Data asupan zat gizi dan air diolah menggunakan program nutrisurvey. Asupan zat gizi meliputi; energi, karbohid- rat, protein, lemak, kalsium, zat besi, zinc, asam folat disajikan dalam bentuk nilai rerata (mean) dan Standar Deviasi (SD). Tingkat asupan air berasal dari 4 sumber yaitu minuman air putih, minuman lainnya (berwarna dan berasa), air dalam makanan, dan air metabolik, yang dihitung: asupan air dibandingkan dengan kebutuhan sehingga dapat dilakukan penilaian tingkat asupan air terhadap kebutuhan. Penyajian data persentase tingkat asupan air dalam bentuk rerata dan standar deviasi. Status hidrasi dalam penelitian menggunakan biomarker standar, yaitu osmolalitas urin dengan kategori $\geq 500 \mathrm{mOsm} / \mathrm{Kg}$ dikatakan hipohidrasi dan $<500 \mathrm{mOsm} / \mathrm{Kg}$ dikatakan normal. Pengujian analisis bivariat menggunakan uji beda t-two independent test untuk melihat perbedaan pada dua kelompok, dan chi-square untuk melihat hubungan karakteristik subjek, sosial ekonomi, status gizi dan asupan zat gizi dan air terhadap status hidrasi ibu hamil. Penelitian ini telah mendapat persetujuan etik yang berasal dari Komisi Etik Penelitian Kesehatan Fakultas Kedokteran Universitas Indonesia, Jakarta berupa Keterangan Lolos Kaji Etik (Ethical Approval) dengan nomor: No.869/UN2.F1/ETHICS/2016 tanggal 10 Oktober 2016 .

\section{HASIL}

Penelitian ini menggunakan osmolalitas urin sebagai indikator dari status hidrasi ibu hamil. Berdasarkan nilai osmolalitas urin terbagi

Tabel 1. Karakteristik Subjek

\begin{tabular}{|c|c|c|c|}
\hline Variabel & $\begin{array}{c}\text { Hipohidrasi } \\
(n=63)\end{array}$ & $\begin{array}{c}\text { Normal } \\
(n=44)\end{array}$ & p-value \\
\hline Umur ibu (tahun) & $26.08 \pm 4.82^{\mathrm{a})}$ & $25.73 \pm 4.64$ & 0.70 \\
\hline Umur kehamilan (mgu) & $16.54 \pm 0.85$ & $16.68 \pm 0.90$ & 0.41 \\
\hline Berat badan $(\mathrm{kg})$ sebelum hamil & $56.57 \pm 14.90$ & $54.06 \pm 7.94$ & 0.31 \\
\hline Berat badan (kg) (trimester ke-2) & $59.82 \pm 15.26$ & $57.74 \pm 8.69$ & 0.41 \\
\hline Tinggi badan $(\mathrm{cm})$ & $154.15 \pm 4.64$ & $154.11 \pm 4.72$ & 0.96 \\
\hline Status gizi sebelum hamil $\left(\mathrm{kg} / \mathrm{m}^{2}\right)$ & & & 0.16 \\
\hline Tidak normal (kurus dan gemuk) & $29(46.00)^{\mathrm{b})}$ & $14(31.80)$ & \\
\hline Normal & $34(54.00)$ & $30(68.20)$ & \\
\hline Lingkar lengan atas $(\mathrm{cm})$ & $27.57 \pm 4.16$ & $27.44 \pm 3.01$ & 0.86 \\
\hline Lingkar pinggang $(\mathrm{cm})$ & $89.41 \pm 11.44$ & $89.27 \pm 7.39$ & 0.94 \\
\hline Lingkar panggul $(\mathrm{cm})$ & $98.22 \pm 11.08$ & $95.02 \pm 15.26$ & 0.21 \\
\hline \multicolumn{4}{|l|}{ Tekanan darah } \\
\hline Sistole $(\mathrm{mmHg})$ & $107.71 \pm 13.11$ & $109.32 \pm 9.07$ & 0.48 \\
\hline Diastole (mmHg) & $68.71 \pm 7.13$ & $69.32 \pm 6.71$ & 0.66 \\
\hline
\end{tabular}

a)mean $\pm \mathrm{SD}$, -test independen. ${ }^{\mathrm{b})} \mathrm{n}(\%)$,chi-square 
Tabel 2. Sosial Ekonomi Berdasarkan Status Hidrasi

\begin{tabular}{|c|c|c|c|}
\hline Variabel & Hipohidrasi $(n=63)$ & Normal $(n=44)$ & p-value \\
\hline \multicolumn{4}{|l|}{ Tingkat Pendidikan Ayah } \\
\hline Rendah & $10(15.90)$ & $3(6.80)$ & 0.23 \\
\hline Tinggi & $53(84.10)$ & $41(93.20)$ & \\
\hline \multicolumn{4}{|l|}{ Tingkat Pendidikan Ibu } \\
\hline Rendah & $6(9.50)$ & $3(6.80)$ & 0.73 \\
\hline Tinggi & $57(90.50)$ & $41(93.20)$ & \\
\hline \multicolumn{4}{|l|}{ Pekerjaan Ayah } \\
\hline Tidak bekerja & $4(6.30)$ & $5(11.40)$ & 0.48 \\
\hline Bekerja & $56(93.70)$ & $39(88.60)$ & \\
\hline \multicolumn{4}{|l|}{ Pekerjaan Ibu } \\
\hline Tidak bekerja & $44(69.80)$ & $29(59.10)$ & 0.30 \\
\hline Bekerja & $19(30.20)$ & $18(40.90)$ & \\
\hline \multicolumn{4}{|l|}{ Pengeluaran } \\
\hline Menengah kebawah & $23(36.50)$ & $20(45.50)$ & 0.42 \\
\hline Menengah keatas & $40(63.50)$ & $24(54.50)$ & \\
\hline \multicolumn{4}{|l|}{ Pengetahuan ibu } \\
\hline Kurang & $20(31.70)$ & $9(20.50)$ & 0.27 \\
\hline Baik & $43(68.30)$ & $35(79.50)$ & \\
\hline
\end{tabular}

${ }^{\text {a) }} \mathrm{n}(\%)$, chi-square

Tabel 3. Asupan Zat Gizi dan Air

\begin{tabular}{lcccc}
\hline \multicolumn{1}{c}{ Variabel } & Hipohidrasi $(\mathbf{n}=\mathbf{6 3})$ & Normal $(\mathbf{n}=\mathbf{4 4})$ & t-test & p-value \\
\hline${\text { Energi }(\mathrm{kkal})^{\mathrm{b})}}_{\text {Karbohidrat }(\mathrm{g})^{\mathrm{b})}}$ & $\left.1445.29 \pm 448.84^{\mathrm{a}}\right)$ & $1648.19 \pm 543.00$ & -2.10 & 0.03 \\
Protein (g) & $182.70 \pm 59.22$ & $211.37 \pm 68.21$ & -2.31 & 0.02 \\
Lemak (g) & $49.81 \pm 15.89$ & $66.70 \pm 76.80$ & -1.69 & 0.09 \\
Kalsium (mg) & $58.32 \pm 24.38$ & $66.47 \pm 27.44$ & -1.61 & 0.10 \\
Zat besi (mg) & $280.48 \pm 245.01$ & $422.32 \pm 531.53$ & -1.85 & 0.06 \\
Zinc (mg) b) & $7.46 \pm 5.53$ & $9.05 \pm 5.95$ & -1.41 & 0.15 \\
Asam folat (mg) & $5.36 \pm 1.80$ & $6.49 \pm 3.69$ & -2.09 & 0.03 \\
Total asupan air (ml) & $129.08 \pm 63.57$ & $119.08 \pm 54.85$ & 0.84 & 0.40 \\
Tingkat asupan air $(\%)$ & $2053.75 \pm 572.11$ & $2251.60 \pm 625.33$ & -1.69 & 0.09 \\
\end{tabular}

a) mean \pm SD, $t$-test independent, ${ }^{\mathrm{b}} \mathrm{p}<0.05$

atas 2 kelompok, yaitu hipohidrasi $58.90 \%$ dan normal $41.10 \%$. Nilai rerata osmolalitas urin pada kelompok hipohidrasi dan normal, masingmasing adalah $838.78 \pm 172.35 \mathrm{mOsm} / \mathrm{Kg}$ dan $268.05 \pm 116.64 \mathrm{mOsm} / \mathrm{Kg}$ (Tabel 1). Sementara, nilai rerata osmolalitas urin secara keseluruhan yaitu $604.08 \pm 320.16 \mathrm{mOsm} / \mathrm{Kg}$. Nilai ini berada di atas nilai batas normal yaitu $\geq 500 \mathrm{mOsm} / \mathrm{Kg}$.

Subjek dalam penelitian ini berjumlah 107 ibu hamil yang bersedia untuk diukur, wawancara dan diambil darah serta urin. Seluruh karakteristik subjek berupa umur, umur kehamilan, berat badan, tinggi badan, status gizi sebelum hamil, lingkar lengan atas, lingkar pinggang, lingkar panggul, dan tekanan darah tidak ada perbedaan yang signifikan di antara dua kelompok ( $\mathrm{p} \geq 0.05)$ (Tabel 1). Nilai tekanan darah dari kedua kelompok berada dalam kategori normal, yaitu kelompok hipohidrasi $107.71 / 68.71 \mathrm{mmHg}$ dan normal $109.32 / 69.32$ $\mathrm{mmHg}$. Sebagian besar subjek dalam penelitian ini memiliki status gizi sebelum hamil pada kategori normal yaitu kelompok hipohidrasi (54.00\%) dan normal $(68.20 \%)$.

Keadaan sosial-ekonomi merupakan salah satu hal yang berpengaruh terhadap asupan zat gizi dan air. Penelitian ini menemukan tidak terdapat hubungan yang signifikan pada tingkat pendidikan ayah dan ibu, pekerjaan ayah dan ibu, pengeluaran 
rumah tangga, dan pengetahuan ibu $(\mathrm{p} \geq 0,05)$ (Tabel 2). Namun, prevalensi tingkat pendidikan ayah yang termasuk dalam kategori tinggi lebih dari $50 \%$ berada di kedua kelompok yaitu, hipohidrasi $(90.50 \%)$ dan normal (93.20\%).

Penelitian menunjukkan bahwa terdapat perbedaan asupan energi, karbohidrat, dan zinc pada kedua kelompok $(\mathrm{p}<0.05)$, tetapi tidak ditemukan perbedaan asupan zat gizi (protein, lemak, kalsium, zat besi dan asam folat) dan air di kedua kelompok $(\mathrm{p} \geq 0.05)$ (Tabel 3). Sementara total asupan air dan tingkat asupan air pada kelompok ibu hipohidrasi dan normal berada pada kategori deficit (kurang) atau $<90 \%$.

\section{PEMBAHASAN}

Osmolalitas urin merupakan salah satu biomarker yang digunakan untuk menilai status hidrasi seseorang. Dalam penelitian ini, indikator yang digunakan untuk mengkategorikan status hidrasi yaitu dengan nilai osmolalitas urin. Adapun rerata nilai osmolalitas urin di kedua kelompok berada di atas nilai normal $\geq 500 \mathrm{mOsm} / \mathrm{Kg}$, hal ini berarti subjek mengalami dehidrasi. ${ }^{14}$ Penelitian lain menemukan warna urin dapat digunakan sebagai biomarker untuk indikator status hidrasi pada orang dewasa baik laki-laki, wanita, ibu hamil, anak-anak dan atlet. Selain itu, menyebutkan bahwa warna urin merupakan biomarker yang valid, mudah, dan sederhana. ${ }^{15-17}$ Selain itu, beberapa penelitian menyebutkan bahwa osmolalitas urin dan serum merupakan biomarker yang cocok untuk melihat status hidrasi seseorang dalam kondisi tertentu. ${ }^{18,19}$

Umur subjek pada penelitian ini berada dalam kategori normal sebagai umur reproduksi yaitu kisaran 14-49 tahun..$^{20}$ Berat badan dan Indeks Massa Tubuh (IMT) yang tercermin dalam status gizi ibu sebelum hamil merupakan salah satu faktor yang dapat mempengaruhi berat badan bayi lahir. Dalam penelitian lain menyebutkan bahwa IMT ibu sebelum hamil dapat mempengaruhi kenaikan berat badan ibu selama kehamilan. ${ }^{21}$

Penelitian ini tidak menemukan adanya hubungan faktor sosial ekonomi dan status hidrasi pada ibu hamil. Dalam penelitian lain menyebutkan bahwa pada ibu hamil dengan sosial-ekonomi menengah ke bawah rentan terhadap kejadian $\mathrm{Hy}$ peremesis Gravidarum dan dehidrasi, serta risiko kehamilan seperti berat bayi lahir rendah., ${ }^{2,22} \mathrm{Pe}$ nelitian lain mengungkapkan bahwa untuk memajukan negara salah satunya adalah dengan menurunkan angka gizi buruk dan kematian, upaya yang diperlukan yaitu pemberdayaan perempuan, sistem pertanian dan pangan, pendidikan, pekerjaan, perlindungan sosial, dan pengamanan jaringan. ${ }^{23}$ Meskipun tidak terdapat hubungan faktor sosial ekonomi dan status hidrasi, prevalensi di kedua kelompok menunjukkan bahwa tingkat pendidikan ayah dengan kategori tinggi $>50 \%$. Dengan demikian, pendidikan ayah dimungkinkan dapat membantu perubahan perilaku ibu hamil selama masa kehamilan. Penelitian lain menemukan terdapat hubungan pada tingkat pendidikan dan pekerjaan ayah serta ibu dengan kesehatan anak, tetapi dengan pengeluaran rumah tangga tidak ada hubungan dengan status kesehatan. ${ }^{24}$ Pendidikan ayah berpengaruh terhadap dukungan selama kehamilan yang dapat mengurangi kejadian berat bayi lahir rendah. ${ }^{25}$ Pendidikan tinggi pada ayah, yang mana ayah merupakan kepala rumah tangga dapat memudahkan tenaga kesehatan untuk memberikan informasi kesehatan untuk keluarga, khususnya pada ibu hamil. ${ }^{26,27}$ Dalam penelitian lain menemukan bahwa kekurangan dari faktor sosialekonomi dapat meningkatkan risiko pertumbuhan janin terhambat dan kelahiran prematur (output kehamilan) ${ }^{28}$ Dengan demikian, faktor sosialekonomi masih tetap menjadi perhatian dalam upaya perbaikan status kesehatan keluarga.

Asupan zat gizi dan air pada ibu merupakan hal yang penting dalam menunjang proses kehamilan, yang akan berpengaruh terhadap kesehatan ibu dan janin, hasil kelahiran, dan risiko penyakit kronis pada keturunan. ${ }^{29,30}$ Penelitian ini menemukan perbedaan asupan energi, karbohidrat dan zinc pada kedua kelompok. Namun, tidak pada asupan protein, lemak, kalsium, zat besi, asam folat, dan tingkat asupan air. Adapun rerata asupan zat gizi bila dibandingkan dengan Angka Kecukupan Gizi (AKG) untuk ibu hamil seperti energi, karbohidrat, protein, lemak, kalsium, zat besi, zinc, dan asam folat berada di bawah rerata nilai AKG 2014. ${ }^{31}$ Pada asupan air kedua kelompok berada di kategori deficit (kurang), yaitu $<90 \%$. Dengan demikian, perbedaan beberapa asupan zat gizi pada kedua kelompok dimungkinkan bersumber pada kualitas dan kuan- 
titas bahan makanan, hal ini akan berdampak pada bayi yang dilahirkan baik pertumbuhan secara fisik maupun mental. ${ }^{32,33}$

Kebutuhan cairan pada ibu hamil usia 1418 tahun dan 19-50 tahun sebesar 3.0 L/hari, berfungsi mempertahankan homeostasis dalam tubuh dan memungkinkan untuk transportasi zat gizi ke sel dan penghapusan ekskresi limbah produk dari sisa metabolisme. Kebutuhan ini bersumber dari semua minuman termasuk air, kelembaban pada makanan (kelembaban tinggi pada makanan termasuk semangka, daging, sup, dll). ${ }^{34}$ Dalam hal ini, peranan faktor sosial-ekonomi, khususnya pendidikan dapat mempengaruhi kebiasaan atau pola asupan zat gizi seimbang pada ibu hamil. ${ }^{35,36}$ Hal ini berarti, faktor sosial-ekonomi seseorang akan mempengaruhi daya beli bahan makanan dan minuman untuk memenuhi kebutuhan gizi selama kehamilan yang akan memberikan dampak pada status gizi, asupan air mempengaruhi status hidrasi ibu dan transfer zat gizi ibu ke janin sehingga memberikan dampak pada hasil kehamilan. ${ }^{37}$ Secara jelas bahwa karakteristik subjek ibu (usia, usia kehamilan), status gizi, sosial-ekonomi, dan asupan zat gizi (protein, lemak, kalsium, zat besi, asam folat, total asupan air dan tingkat asupan air) dimungkinkan memberikan kontribusi terhadap status hidrasi ibu selama kehamilan.

\section{KESIMPULAN DAN SARAN}

Penelitian ini mengungkapkan bahwa tidak terdapat hubungan signifikan karakteristik subjek dan status gizi dengan status hidrasi. Tidak terdapat hubungan signifikan pada pendidikan ayah dan ibu, pekerjaan ayah dan ibu, serta pengeluaran rumah tangga dengan status hidrasi. Selain itu, penelitian ini juga tidak menemukan perbedaan signifikan pada asupan zat gizi (protein, lemak, kalsium, zat besi, asam folat, total asupan air dan tingkat asupan air) pada ibu hamil yang hipohidrasi dan normal. Namun, ditemukan perbedaan pada asupan energi, karbohidrat, dan zinc pada kedua kelompok ibu hipohidrasi dan normal. Dengan demikian, pada kasus kehamilan ibu harus tetap memperhatikan asupan zat gizi khususnya energi, karbohidrat, protein, zinc, dan air sebanyak $3.0 \mathrm{~L} /$ hari untuk mendukung tumbuh kembang janin dalam 1000 hari pertama kehidupan. Perlu penelitian lanjutan terkait sosial-ekonomi dan asupan zat gizi serta air pada kasus kehamilan sebagai salah satu faktor dalam mengurangi risiko kehamilan.

\section{UCAPAN TERIMA KASIH}

Penelitian ini sepenuhnya didanai oleh Yayasan Institut Danone Indonesia. Pandangan dalam penelitian ini dikemukakan oleh Peneliti dan tidak mencerminkan pandangan dari Yayasan Institut Danone Indonesia. Terima kasih juga kepada petugas Laboratorium Terakreditasi Prodia yang membantu mengumpulkan data, dan petugas yang membantu dalam pengumpulan data di lapangan. Tim peneliti menyatakan tidak ada konflik kepentingan atas hasil penelitian ini.

\section{DAFTAR PUSTAKA}

1. Pouchieu C, Le'vy R, Faure C, Andreeva VA, Galan P, et al. Socioeconomic, Lifestyle and Dietary Factors Associated with Dietary Supplement Use during Pregnancy. PLoS ONE. 2013;8(8):e70733.DOI:10.1371/journal. pone.0070733.

2. Karaca C, Guler N, Yazar A, Camlica H, Demir K, Yildirim G. Is Lower Socio Economic Status a Risk Factor for Helicobacter Pylori Infection in Pregnant Women with Hyperemesis Gravidarum?. Turk J Gastroenterol. 2004; 15(2): 86-89.

3. Niebyl JR. Nausea and Vomiting in Pregnancy. N Engl J Med. 2010;363:1544-50.

4. Jarvis S, Nelson-Piercy C. Management of Nausea and Vomiting in Pregnancy. BMJ. 2011;42:d3606. DOI: 10.1136/bmj.d3606.

5. Maltepe $\mathrm{C}$ dan Gideon K. The Management of Nausea and Vomiting of Pregnancy and Hyperemesis Gravidarum. J Popul Ther Clin Pharmacol. 2013; 20(2):e184-e192.

6. Viljoen E, Janicke V, Nelene K, Alfred M. A Systematic Review and Meta-Analysis of the Effect and Safety of Ginger in the Treatment of Pregnancy-Associated Nausea and Vomiting. Nutrition Journal. 2014;19(13): 20.

7. Vandraas KF, Å.V. Vikanes, N.C. Støer, S. Vangen, P. Magnus, A.M. Grjibovski. Is Hyperemesis Gravidarum Associated with Placental Weight and the Placental Weight to Birth Weight Ratio? A Population-Based Norwegian Cohort Study. Placenta. 2013;34(11):990-4. DOI : 10.1016/j.placenta.2013.08.001. 
8. Lacasse A, rey E, Ferreira E, Morin C, Berard A. Nausea and Vomiting of Pregnancy: What About Quality of Life?. BJOG. 2008;115:14841493. DOI:10.1111/j.1471-0528.2008.01891. $\mathrm{x}$.

9. Carmichael, A. Initial Treatment of Dehydration for Severe Acute Malnutrition. e-Library of Evidence for Nutrition Actions (eLENA). (WHO 2011). [diakses 22 September 2015]. Available at: http://www.who.int/elena/titles/ bbc/dehydration sam/en/.

10. Mulyani EY, Hardinsyah, Briawan D, Santoso BI. Hydration Status of Pregnant Women in West Jakarta. Asia Pac J Clin Nutr. 2017;26(Suppl 1):S26-S30. DOI: 10.6133/ apjen.062017.s14.

11. Louik C, Hernandez-Diaz S, Werler MM, Mitchell AA. Nausea and Vomiting in Pregnancy: Maternal Characteristics and Risk Factors. Paediatr Perinat Epidemiol. 2006; 20(4):270-278.

12. Chortatos A, Haugen M, Iversen PO, Vikanes A, Magnus P, Veierod MB. Nause and Vomiting in Pregnancy: Associations with Maternal Gestational Diet and Lifestyle Factors in the Norwegian Mother and Child Cohort Study. BJOG. 2013; 120:1642-1653.

13. Malisova $\mathrm{O}$, Athanasios $\mathrm{P}$, Anastasia N, Vassiliki B, Aristides A, Antonis Z, Maria K. Estimations of Water Balance after Validating and Administering the Water Balance Questionnaire in Pregnant Women. Int J Food Sci Nutr. 2014; 65(3): 280-285.

14. Armstrong LE, Johnson EC, Munoz CX, Swokla B, Le Bellego L, Jimenez L, Casa DJ, Maresh CM. Hydration Biomarkers and Dietary Fluid Consumption of Women. J Acad Nutr Diet. 2012;112(7):1056-61.

15. McKenzie AL et.al. Urine Color as an Indicator of Urine Concentration in Pregnant and Lactating Women. Eur J Nutr. 2017; Feb;56(1):355-362.DOI:10.1007/s00394015-1085-9.

16. Shirreffs SM. Markers of Hydration Status. Eur J Nutr. 2003;57 (Suppl 2):S6-S9.

17. Campos R, Montenegro-Bethancourt G, Vossenaar M, Doak CM, Solomons NW. Volume, Frequency, and Participant in Plain Drinking Water Consumption by Third and
Fourth-Grades Schoolchildren in Quetzaltenango, Guatemala. Asia Pac J Clin Nutr. 2009;18:164-70.

18. Kavouras SA, Johnson EC, Bougatsas D, Arnaoutis G, Panagiotakos DB, Perrier E, Klein A. Validation of Urine Scale for Assessment of Urine Osmolality in Healthy Children. Eur J Nutr. 2016;55:907-915. DOI: 10.1007/ s00394-015-0905-02.

19. Youhanna S, Bankir L, Jungers P, Porteous D, Polasek O, Bochua M, Hayward C, Devuyst O. Validation of Surrogates of Urine Osmolality in Population Studies. Am J Nephrol 2017;46:26-36.

20. World Health Organization. Reproductive Health Indicators. Geneva : World Health Organization; 2006.

21. Nurhayati E. Indeks Massa Tubuh (IMT) Pra Hamil dan Kenaikan Berat Badan Ibu Selama Hamil Berhubungan dengan Berat Badan Bayi Lahir. Jurnal Ners dan Kebidanan Indonesia. 2015;4(1-5).

22. Hack M, Daniel JF, Mark S, Lydia C, Elaine B, Nancy K. Outcomes in Young Adulthood for Very Low Birth Weight Infants. N Engl J Med. 2002; 346:149-157. DOI: 10.1056/NEJMoa010856.

23. Bhutta ZA, Jai KD, Arjumand R, Michelle FG, Neff W, Susan H, Patrick W, Anna L, Robert EB. Evidence Based Interventions for Improvement of Maternal and Child Nutrition: What Can be Done and at What Cost? The Lancet. 2013;382(9890):452-477. DOI : 10.1016/S0140-6736(13)60996-4.

24. Bener A, Mohammad SE, Hale ZB, Qutayba $H$. The Impact of Vitamin D Deficiency on Asthma, Allergic Rhinitis and Wheezing in Children: An Emerging Public Health Problem. J Family Community Med. 2014; 21(3): 154-161. DOI: $10.4103 / 2230-8229.142967$.

25. Shah MK, Rebekah EG, Katherine PT. Partner Support and Impact on Birth Outcomes among Teen Pregnancies in the United States. J Pediatr Adolesc Gynecol. 2014; 27(1):14-19. DOI: 10.1016/j.jpag.2013.08.002.

26. Hui Li Poh, Serena Siew LK, Hui Cheng LS, Hong-Gu He. First-Time Fathers' Experiences and Needs During Pregnancy and Childbirth: A Descriptive Qualitative Study. Midwifery. 
2014; 30:6:779-787.

27. Backstrom, C, Hertfelt Wahn, E. Support During Labour: First-Time Fathers' Descriptions of Requested and Received Support During the Birth of Their Child. Midwifery. 2011;27:67-73.

28. Kramer MS, L. Seguin, J Lydon, L. Goulet. Socio-Economic Disparities in Pregnancy Outcome: Why do the Poor Fare so Poorly?. Paediatric and Perinatal Epidemiology. 2001;14:issue 3. p:194-210. DOI : 10.1046/j.1365-3016.2000.00266.x.

29. Blumfield ML dan Clare EC. High-Protein Diets During Pregnancy: Healthful or Harmful for off Spring?. Am J Clin Nutr. 2014;100:9935.

30. Englund-Ogge L, Anne LB, Verena S, Margareta $\mathrm{H}$, Bryndis EB, Ronny M, Helle MM, Bo J. Maternal Dietary Patterns and Preterm Delivery: Results from Large Prospective Cohort Study. BMJ. 2014;348:g1446.

31. Kemenkes RI. Angka Kecukupan Gizi yang Dianjurkan Bagi Bangsa Indonesia. Jakarta : Direktorat Jenderal Bina Gizi dan Kesehatan Ibu dan Anak, Kementerian Kesehatan Republik Indonesia; 2014.

32. Wiltbank MC et al. Effects of Energy and Protein Nutrition in the Dam on Embryonic Development. Anim. Reprod. 2014;11(3):168-
182.

33. Emmett PM, Jones LR, Golding J. Pregnancy Diet and Associated Outcomes in the Avon Longitudinal Study of Parents and Children. Nutrition Reviews. 2015;73(S3):154-174. DOI: $10.1093 /$ nutrit/nuv053.

34. The Institute International Medicine (IOM). Dietary Reference Intakes for Water, Potassium, Sodium, Chloride, and Sulfate. 2004. Available from : https://www.nap.edu/ read/10925/chapter/1\#iv.

35. Fitri YP, Dodik B, Ikeu T, Siti M. Tingkat Kecukupan dan Bioavailabilitas Asupan Zat Besi pada Ibu Hamil di Kota Tangerang. Media Kesehatan Masyarakat Indonesia. 2016;12(3): 185-191. DOI : 10.30597/mkmi.v12i3.1083

36. Lubis Z, Jumirah J, Maya F. Karakteristik, Asupan Gizi dan Kejadian Anemia pada Ibu Hamil. Media Kesehatan Masyarakat Indonesia. 2017;13(3):224-229. DOI : 10.30597/ mkmi.v13i3.2670.

37. Rahman MS, Howlader T, Masud MS, Rahman ML. Association of Low Birth Weight with Malnutrition in Children under Five Years in Bangladesh: Do Mother's Education, Socio-Economic Status, and Birth Interval Matter? PLoS ONE. 2016;11(6):e0157814. DOI:10.1371/journal.pone.0157814. 